\title{
The Origin of Fracture in the I-ECAP of AZ31B Magnesium Alloy
}

\author{
MICHAL GZYL, ANDRZEJ ROSOCHOWSKI, SONIA BOCZKAL, \\ and MUHAMMAD JAWAD QARNI
}

\begin{abstract}
Magnesium alloys are very promising materials for weight-saving structural applications due to their low density, comparing to other metals and alloys currently used. However, they usually suffer from a limited formability at room temperature and low strength. In order to overcome those issues, processes of severe plastic deformation (SPD) can be utilized to improve mechanical properties, but processing parameters need to be selected with care to avoid fracture, very often observed for those alloys during forming. In the current work, the AZ31B magnesium alloy was subjected to SPD by incremental equal-channel angular pressing (I-ECAP) at temperatures varying from $398 \mathrm{~K}$ to $525 \mathrm{~K}\left(125{ }^{\circ} \mathrm{C}\right.$ to $\left.250{ }^{\circ} \mathrm{C}\right)$ to determine the window of allowable processing parameters. The effects of initial grain size and billet rotation scheme on the occurrence of fracture during I-ECAP were investigated. The initial grain size ranged from 1.5 to $40 \mu \mathrm{m}$ and the I-ECAP routes tested were A, $\mathrm{B}_{\mathrm{C}}$, and C. Microstructures of the processed billets were characterized before and after I-ECAP. It was found that a fine-grained and homogenous microstructure was required to avoid fracture at low temperatures. Strain localization arising from a stress relaxation within recrystallized regions, namely twins and finegrained zones, was shown to be responsible for the generation of microcracks. Based on the I-ECAP experiments and available literature data for ECAP, a power law between the initial grain size and processing conditions, described by a Zener-Hollomon parameter, has been proposed. Finally, processing by various routes at $473 \mathrm{~K}\left(200{ }^{\circ} \mathrm{C}\right)$ revealed that route A was less prone to fracture than routes $\mathrm{B}_{\mathrm{C}}$ and $\mathrm{C}$.
\end{abstract}

DOI: $10.1007 / \mathrm{s} 11661-015-3069-\mathrm{z}$

(C) The Minerals, Metals \& Materials Society and ASM International 2015

\section{INTRODUCTION}

EQUAL-CHANNEL angular pressing (ECAP) is one of the most popular methods of severe plastic deformation used by researchers worldwide to improve mechanical properties of metals and alloys. The concept of the process is relatively simple; a billet is pressed through an angled channel, which has the same inlet and outlet dimensions. ${ }^{[1,2]}$ Therefore, large strain (true strain -1) is introduced in the billet by simple shear without affecting its shape. ECAP can be realized using different processing routes: ${ }^{[3]}$ route $\mathrm{A}$ means that a billet is not rotated about its axis between subsequent passes of ECAP, and routes $\mathrm{B}_{\mathrm{C}}$ and $\mathrm{C}$ indicate rotation by $90 \mathrm{deg}$ and $180 \mathrm{deg}$, respectively.

Magnesium alloys, which are the lightest structural metallic materials currently used, could also take

MICHAL GZYL, Research Associate, and MUHAMMAD JAWAD QARNI, Knowledge Exchange Associate, are with the Advanced Forming Research Centre, University of Strathclyde, 85 Inchinnan Drive, Renfrew PA4 9LJ, U.K. Contact e-mail: michal.gzyl@strath.ac.uk ANDRZEJ ROSOCHOWSKI, Reader, is with the Design, Manufacture and Engineering Management, University of Strathclyde, James Weir Building, 75 Montrose Street, Glasgow G1 1XJ, U.K. SONIA BOCZKAL, Assistant Professor, is with the Light Metals Division, Institute of Non-Ferrous Metals in Gliwice, ul. Pilsudskiego 19, 32-050 Skawina, Poland.

Manuscript submitted December 19, 2014.

Article published online July 29, 2015 advantage of ECAP. It has been already shown in the literature that low formability of the most common wrought magnesium alloy, AZ31, can be improved by ECAP followed by annealing. ${ }^{[4]}$ More recently, ECAP was confirmed to be successful in improving strength of the same alloy by lowering processing temperature. ${ }^{[5]}$ Finally, low corrosion resistance of magnesium alloys could be also enhanced by ECAP, as it was reported for ZK60. ${ }^{[6]}$

Despite a lot of interesting results obtained for magnesium alloys after ECAP, selection of processing parameters is still a challenge. Unstable flow, which can lead to fracture, is observed when temperature is too low or pressing speed is too high. Kang et al. ${ }^{[7]}$ investigated effects of temperature and ram speed on the fracture behavior of AZ31 subjected to one pass of ECAP. They showed that the material underwent fracture by segmentation at $423 \mathrm{~K}\left(150{ }^{\circ} \mathrm{C}\right)$ even with pressing speed as low as $10 \mathrm{~mm} / \mathrm{min}$, which corresponded to a strain rate of $0.01 \mathrm{~s}^{-1}$. Moreover, processing at $473 \mathrm{~K}\left(200{ }^{\circ} \mathrm{C}\right)$ was successful only with ram velocity not exceeding $25 \mathrm{~mm} /$ min. Finally, they showed that pressing speed can be increased to $300 \mathrm{~mm} / \mathrm{min}$ when temperature is raised to $523 \mathrm{~K}\left(250^{\circ} \mathrm{C}\right)$.

Although temperature increase helps with avoiding fracture, lower processing temperature allows obtaining smaller grain size, which can result in higher strength ${ }^{[5]}$ or low-temperature superplasticity. ${ }^{[8,9]}$ Various solutions 
were proposed in order to improve formability of magnesium alloys during ECAP, including applying back-pressure, ${ }^{[10]}$ increasing strain rate sensitivity of a material by direct extrusion, ${ }^{[11]}$ increasing die angle, ${ }^{[11]}$ decreasing temperature with subsequent passes, ${ }^{[5,12-14]}$ and decreasing strain rate. ${ }^{[7,15]}$ Gradual temperature decrease was shown to be effective in lowering temperature below $473 \mathrm{~K}\left(200{ }^{\circ} \mathrm{C}\right)$; therefore, it was also attempted in this work.

Despite ECAP being a very popular tool for grain refinement, it is not suitable for a large-scale production of ultra-fine-grained materials with improved properties. The main drawback of the conventional ECAP is a limitation of the billet's length due to a high force required to press a long bar through the channel. In order to solve this problem, incremental ECAP (I-ECAP) was proposed by Rosochowski and Olejnik. ${ }^{[16]}$ The schematic illustration of the process is shown in Figure 1. In I-ECAP, the stages of material feeding and plastic deformation are separated, which reduces the feeding force significantly. The tool configuration consists of a punch working in a reciprocating manner and a feeder feeding the material in incremental steps, synchronized with the punch movement. As long as the feeding stroke is appropriately small, the subsequent shear zones overlap, giving a uniform strain distribution along the billet. I-ECAP can be used for processing long bars, ${ }^{[17]}$ plates, ${ }^{[18]}$ and sheets. ${ }^{[19]}$ It has also been shown recently that it can be successfully applied to refine grain size in AZ31B magnesium alloy. ${ }^{[20,21]}$ The preliminary results from I-ECAP experiments investigating the effect of grain size on formability in I-ECAP have been already published in our previous paper. ${ }^{[2]}$ The work presented here has been extended by microstructural characterization, investigation of route effects on formability, and literature review reflecting similarities between fracture behavior of AZ31B magnesium alloy subjected to I-ECAP and conventional ECAP. Relations between mechanical properties and microstructures of the samples successfully I-ECAPed in this work have been published in the other articles. ${ }^{[20,23]}$

The goal of this work was to investigate how the initial grain size and the processing route affect formability of magnesium alloys during I-ECAP. Experiments were conducted at different temperatures in order to determine the window of allowable processing param-

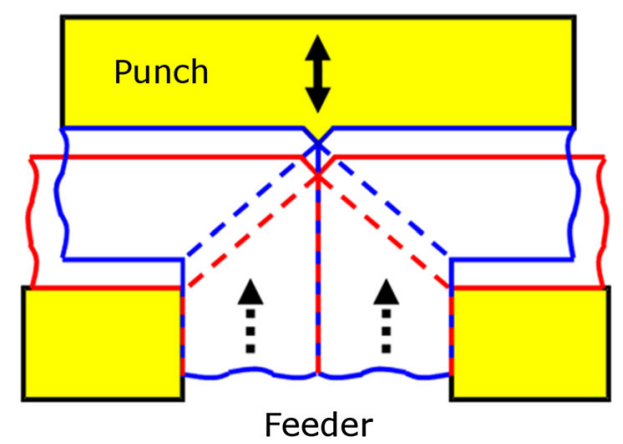

Fig. 1-Schematic illustration of the double-billet I-ECAP process. eters. Microstructures of billets I-ECAPed at different conditions were examined in order to identify the origin of fracture.

\section{MATERIAL}

A commercial wrought magnesium alloy, AZ31B (Mg-3 pet Al-1 pet Zn-0.5 pct $\mathrm{Mn}$ ), was used in this work. Billets for I-ECAP were machined from an extruded rod (16 $\mathrm{mm}$ in diameter) and a rolled plate (20 $\mathrm{mm}$ thick) along extrusion and rolling directions, respectively. SEM-EBSD structure characterization was performed along extrusion and rolling directions before running experiments. It was revealed that the materials exhibited significantly different grain sizes, $8 \mu \mathrm{m}$ for the plate and bimodal $10 \mu \mathrm{m} / 50 \mu \mathrm{m}$ for the rod; the values were obtained by a linear intercept method to remain consistent with literature data for ECAP cited in this article. It is apparent from Figure 2 that microstructure of the rod is much more heterogeneous than the plate. The area in Figure 2(a) is dominated by coarse grains $\sim 50 \mu \mathrm{m}$ surrounded by colonies of smaller grains with a size of 10 to $20 \mu \mathrm{m}$ (Figure 2(b)). Microstructure of the plate is homogenous with only little fraction of coarse grains $\sim 30 \mu \mathrm{m}$ (Figures 2(d) and (e)). Textures shown in Figures 2(c) and (f) are the usual strong fiber textures observed after extrusion and rolling of magnesium alloys. It can be seen that the $c$-axes of the hexagonal cells are aligned perpendicularly to the direction of extrusion as well as rolling.

\section{EXPERIMENTAL PROCEDURE}

I-ECAP experiments conducted in this work were carried out on a $1 \mathrm{MN}$ hydraulic servo press. The double-billet variant of the process, with a die angle of $90 \mathrm{deg}$, was realized as shown in Figure 1. ${ }^{[2]}$ Billets with the cross-sectional dimensions $10 \times 10 \mathrm{~mm}^{2}$ were fed using a motor-driven screw jack whose action was synchronized with the reciprocating movement of the punch. The feeding stroke was $0.2 \mathrm{~mm}$. The punch movement followed an externally generated sine waveform with a frequency of $0.5 \mathrm{~Hz}$ and a peak-to-peak amplitude of $2 \mathrm{~mm}$. An effective strain rate corresponding to the given processing parameters was $0.8 \mathrm{~s}^{-1}$, as obtained from the finite element (FE) simulation. Heating of billets was realized by holding them for 15 minutes prior to processing in the preheated die. The die temperature during processing was kept constant within $\pm 2{ }^{\circ} \mathrm{C}$, based on the readings obtained from the thermocouple located $15 \mathrm{~mm}$ from the deformation zone. The billets were processed by different routes, A, $\mathrm{B}_{\mathrm{C}}$, and $\mathrm{C}$, at temperatures varying from $398 \mathrm{~K}$ to $523 \mathrm{~K}\left(125^{\circ} \mathrm{C}\right.$ to $\left.250{ }^{\circ} \mathrm{C}\right)$.

The influence of initial grain size on formability of AZ31B was studied by conducting I-ECAP experiments using the billets machined from the extruded rod and from the rolled plate. The billets were not rotated between subsequent passes (route A) in this part of 


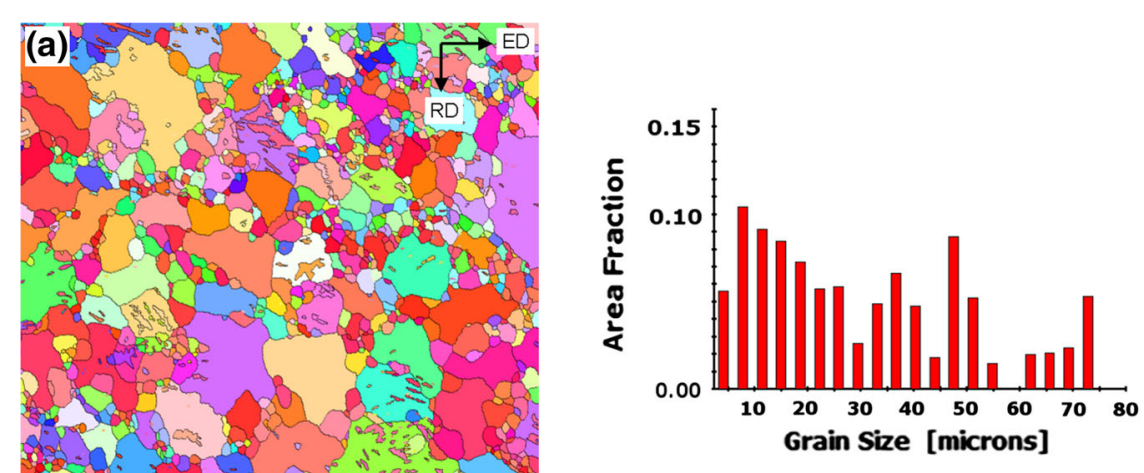

(b)



(e)

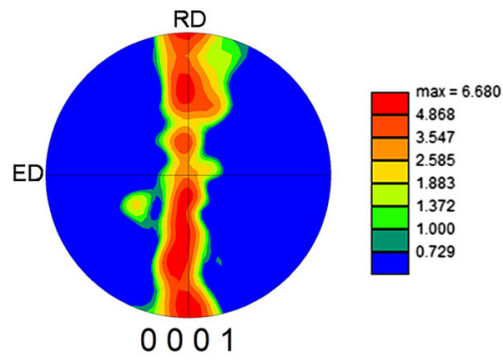

(c)



(f)

Fig. 2-Microstructures, grain size distribution charts, and textures of the as-supplied extruded rod ( $a$ through $c$ ) and rolled plate $(d$ through $f$ ). Symbol explanations: ED: extrusion direction, ND: normal direction of the plate, RD in images (a, c): radial direction of the rod, and RD in images $(\mathrm{d}, \mathrm{f})$ : rolling direction of the plate (Color figure online).

experimental campaign. The extruded rod was subjected to the following processing paths:

1. One pass at $473 \mathrm{~K}\left(200^{\circ} \mathrm{C}\right)$,

2. Two passes at $523 \mathrm{~K}\left(250{ }^{\circ} \mathrm{C}\right)+$ one pass at $473 \mathrm{~K}$ $\left(200{ }^{\circ} \mathrm{C}\right)$, and

3. Four passes at $523 \mathrm{~K}\left(250^{\circ} \mathrm{C}\right)+$ two passes at $473 \mathrm{~K}\left(200{ }^{\circ} \mathrm{C}\right)$.

The following paths were used for the rolled plate:

1. One pass at $448 \mathrm{~K}\left(175^{\circ} \mathrm{C}\right)$,

2. One pass at $473 \mathrm{~K}\left(200{ }^{\circ} \mathrm{C}\right)+$ one pass at $448 \mathrm{~K}$ $\left(175^{\circ} \mathrm{C}\right)+$ two passes at $423 \mathrm{~K}\left(150^{\circ} \mathrm{C}\right)$, and

3. One pass at $473 \mathrm{~K}\left(200{ }^{\circ} \mathrm{C}\right)+$ one pass at $448 \mathrm{~K}$ $\left(175{ }^{\circ} \mathrm{C}\right)+$ one pass at $423 \mathrm{~K}\left(150{ }^{\circ} \mathrm{C}\right)+$ one pass at $398 \mathrm{~K}\left(125^{\circ} \mathrm{C}\right)$.

An additional set of experiments was conducted in order to investigate the effect of I-ECAP route on fracture. Only billets machined from the extruded rod were subjected to I-ECAP in this part of experimental campaign. Three different routes of I-ECAP were tested, known in the literature as $\mathrm{A}, \mathrm{B}_{\mathrm{C}}$, and $\mathrm{C}$. Each route indicates different rotation of the billet between consecutive passes: route $A$ means no rotation; in route $B_{C}$ the billet is rotated by 90 deg in the same sense; and route $\mathrm{C}$ means rotation by $180 \mathrm{deg}$. The following processing paths were realized:
1. Four passes at $523 \mathrm{~K}\left(250{ }^{\circ} \mathrm{C}\right)$ by route $\mathrm{A}$,

2. Four passes at $523 \mathrm{~K}\left(250^{\circ} \mathrm{C}\right)$ by route $\mathrm{B}_{\mathrm{C}}$,

3. Four passes at $523 \mathrm{~K}\left(250^{\circ} \mathrm{C}\right)$ by route $\mathrm{C}$,

4. Four passes at $523 \mathrm{~K}\left(250{ }^{\circ} \mathrm{C}\right)+$ two passes at $473 \mathrm{~K}\left(200{ }^{\circ} \mathrm{C}\right)$ by route $\mathrm{A}$,

5. Four passes at $523 \mathrm{~K}\left(250^{\circ} \mathrm{C}\right)+$ two passes at $473 \mathrm{~K}\left(200{ }^{\circ} \mathrm{C}\right)$ by route $\mathrm{B}_{\mathrm{C}}$, and

6. Four passes at $523 \mathrm{~K}\left(250{ }^{\circ} \mathrm{C}\right)+$ two passes at $473 \mathrm{~K}\left(200{ }^{\circ} \mathrm{C}\right)$ by route $\mathrm{C}$.

Microstructures of the I-ECAPed samples were investigated after selected processing steps. For the rod, images were taken after (1) two passes at $523 \mathrm{~K}\left(250{ }^{\circ} \mathrm{C}\right)$ and (2) four passes at $523 \mathrm{~K}\left(250^{\circ} \mathrm{C}\right)$. Microstructure of the plate was examined after (1) one pass at $473 \mathrm{~K}$ $\left(200{ }^{\circ} \mathrm{C}\right)$ and one pass at $448 \mathrm{~K}\left(175^{\circ} \mathrm{C}\right)$ and $(2)$ one pass at $473 \mathrm{~K}\left(200^{\circ} \mathrm{C}\right)$, one pass at $448 \mathrm{~K}\left(175^{\circ} \mathrm{C}\right)$, and one pass at $423 \mathrm{~K}\left(150^{\circ} \mathrm{C}\right)$. Additionally, microstructures in the deformation zones of samples fractured at $473 \mathrm{~K}$ and $448 \mathrm{~K}\left(200{ }^{\circ} \mathrm{C}\right.$ and $\left.175^{\circ} \mathrm{C}\right)$ were studied.

Microstructural characterization was performed on Olympus GX51 optical microscope and HRSEM FEI Inspect F50 equipped with EBSD for analysis of crystallographic orientation. Preparation for optical microscope observations included: grinding using $\mathrm{SiC}$ paper P1200, mechanical polishing using polycrystalline suspensions with particle sizes of 9,3 , and $1 \mu \mathrm{m}$, and final polishing with colloidal silica. After polishing, 
specimens were etched using acetic picral in order to reveal twins and grain boundaries. Samples for EBSD were prepared by ion milling on Leica RES 100. Scans were performed with steps 0.3 and $0.7 \mu \mathrm{m}$ for the areas of $200 \times 200$ and $400 \times 400 \mu \mathrm{m}^{2}$, respectively. The larger area was examined in the case of coarse-grained rod to obtain more reliable data for statistical analysis.

Compressive flow stress curves of the as-received rod and plate were obtained on Instron 5969 machine with the maximum load capacity $50 \mathrm{kN}$. Tests were carried out at room temperature with the initial strain rate $1 \times 10^{-3} \mathrm{~s}^{-1}$. Cylindrical specimens with the diameter of $8 \mathrm{~mm}$ and the height of $10 \mathrm{~mm}$ were cut out along extrusion and rolling directions.

\section{RESULTS}

\section{A. Processing Maps}

Processing maps, displaying the results of I-ECAP experiments, are shown in Figures 3(a) and (b) for the rod and plate, respectively. The coarse-grained rod underwent fracture at $473 \mathrm{~K}\left(200{ }^{\circ} \mathrm{C}\right)$, and temperature rise to $523 \mathrm{~K}\left(250^{\circ} \mathrm{C}\right)$ was necessary to suppress cracking. Then, temperature reduction in the third pass was attempted for the coarse-grained billet after two successful passes at $523 \mathrm{~K}\left(250^{\circ} \mathrm{C}\right)$, but fracture was still observed; however, it was not a massive damage as it was seen after the first pass at $473 \mathrm{~K}\left(200{ }^{\circ} \mathrm{C}\right)$. Surprisingly, it was possible to conduct I-ECAP at $473 \mathrm{~K}\left(200^{\circ} \mathrm{C}\right)$ without fracture using the billet previously subjected to four passes at $523 \mathrm{~K}$ $\left(250{ }^{\circ} \mathrm{C}\right)$. Two passes at $473 \mathrm{~K}\left(200^{\circ} \mathrm{C}\right)$ were performed in order to confirm that material can be successfully processed in these conditions.

The better formability of the fine-grained plate is shown in Figure 3(b). Despite the first unsuccessful attempt at $448 \mathrm{~K}\left(175^{\circ} \mathrm{C}\right)$, it was possible to gradually reduce temperature from $473 \mathrm{~K}$ to $423 \mathrm{~K}\left(200{ }^{\circ} \mathrm{C}\right.$ to $150{ }^{\circ} \mathrm{C}$ ) in three passes of I-ECAP. It shows that both materials exhibit different formabilities during I-ECAP. The second pass at $423 \mathrm{~K}\left(150{ }^{\circ} \mathrm{C}\right)$ (fourth in total) confirmed that AZ31B can be processed at this temperature without fracture. Temperature reduction to $398 \mathrm{~K}$ $\left(125^{\circ} \mathrm{C}\right)$ was also tried after third pass at $423 \mathrm{~K}$ $\left(150^{\circ} \mathrm{C}\right)$; however, the billet was massively damaged. Figure 4 enables comparison between the billets I-ECAPed at $423 \mathrm{~K}$ and $398 \mathrm{~K}\left(150{ }^{\circ} \mathrm{C}\right.$ and $\left.125^{\circ} \mathrm{C}\right)$.

\section{B. Microstructures}

Microstructure evolution during I-ECAP was investigated in order to reveal a relation between grain size and minimum allowable processing temperature. It is apparent from Figure 5(a) that the microstructure of the coarse-grained sample was significantly refined after two passes at $523 \mathrm{~K}\left(250{ }^{\circ} \mathrm{C}\right)$. The average grain size (linear intercept method) was $8 \mu \mathrm{m}$, but it should be noted that the grain size distribution is non-uniform as coarse grains (20 to $30 \mu \mathrm{m})$ are still observed in this sample. The occurrence of a heterogeneous microstructure is very common for magnesium alloys since the grain refinement process in ECAP is believed to be controlled



(a)

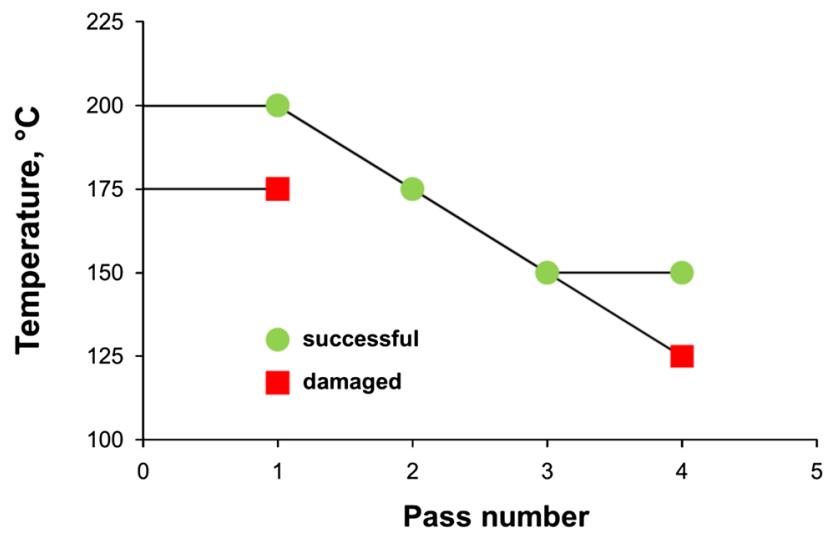

(b)

Fig. 3-I-ECAP processing maps displaying the results of experiments for the coarse-grained rod $(a)$ and the fine-grained plate $(b)$ (Color figure online).

by dynamic recrystallization. ${ }^{[9,13,25,26]}$ Further processing at the same temperature resulted in the grain reduction to $6 \mu \mathrm{m}$ after four passes, as shown in Figure 5(b). Moreover, the microstructure after four passes was also much more homogenous as coarse grains were within $10 \mu \mathrm{m}$. The grain refinement in plate billets subjected to one pass at $473 \mathrm{~K}\left(200{ }^{\circ} \mathrm{C}\right)$ followed by one pass at $448 \mathrm{~K}\left(175^{\circ} \mathrm{C}\right)$ was more efficient than four passes at $523 \mathrm{~K}\left(250{ }^{\circ} \mathrm{C}\right)$ as the average grain size was reduced to $1.5 \mu \mathrm{m}$ from initial $8 \mu \mathrm{m}$ (Figure 5(c)).

The interrupted I-ECAP experiments were conducted in order to reveal microstructures just before entering the shear zone, plane 1 in Figure 6(a), and in the deformation zone, plane 2 in Figure 6(a). The significantly twinned microstructure was observed in the coarse-grained sample (Figure 6(b)), which was fractured during I-ECAP at $473 \mathrm{~K}\left(200^{\circ} \mathrm{C}\right)$. It should be noted here that twins were certainly originating from deformation occurring during I-ECAP as they were not present in the initial microstructure, shown in Figure 2(a). The same zone was investigated in the fine-grained sample after one pass at $473 \mathrm{~K}$ $\left(200{ }^{\circ} \mathrm{C}\right)$ and the second interrupted pass at $448 \mathrm{~K}(175$ ${ }^{\circ} \mathrm{C}$ ), and both pressings were successful. It is apparent from Figure 6(d) that, in contrast to the coarse-grained sample, the microstructure was completely free from twins but the grain size was significantly smaller 


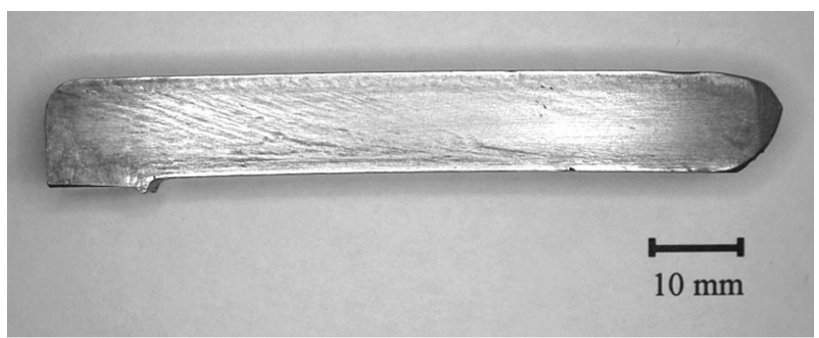

(a)

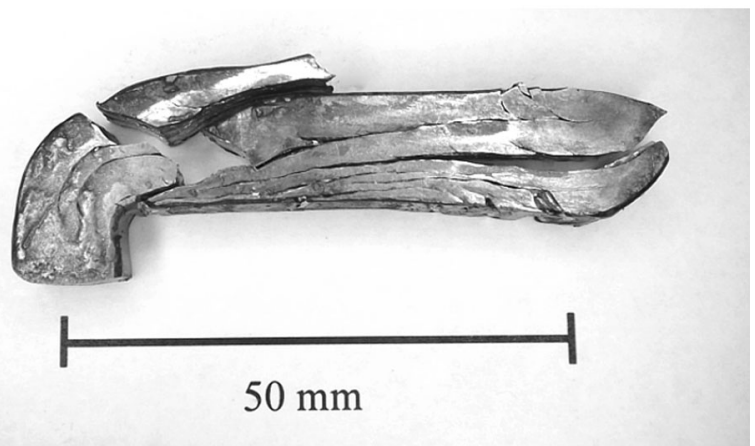

(b)

Fig. 4-Billets cut from plate after final pass of I-ECAP at $423 \mathrm{~K}$ $\left(150{ }^{\circ} \mathrm{C}\right)(a)$ and $398 \mathrm{~K}\left(125^{\circ} \mathrm{C}\right)(b)$.

$(\sim 1.5 \mu \mathrm{m})$. It is shown in Figures 6(c) and (e) that microcracks are surrounded by colonies of small grains in both plate and rod billets, which indicates fracture preceded by strain localization due to the relaxation of stresses. It is also apparent from Figure 6(f) that recrystallization took place inside twins, leading to formation of fine grains within them. It is very likely that the stress relaxation within twinned zones gave rise to strain localization during processing.

\section{Route Effects}

The different schemes of I-ECAP were studied by subjecting the coarse-grained billets to four passes at $523 \mathrm{~K}\left(250{ }^{\circ} \mathrm{C}\right)$ via routes $\mathrm{A}, \mathrm{B}_{\mathrm{C}}$, and $\mathrm{C}$. Looking at cross sections of the billets displayed in Figure 7, it is apparent that different processing paths resulted in the different shapes of the billets. The most symmetrical billet was obtained when route A was used (Figure 7(a)); the dimensions were roughly the same as before I-ECAP. However, completely different results were obtained for route $\mathrm{B}_{\mathrm{C}}$; the billet had an asymmetrical shape as the lower left corner of the exit channel of the die was not filled completely by the material, as shown in Figure $7(\mathrm{~b})$. The billet subjected to route $\mathrm{C}$ (Figure 7(c)) exhibited the shape similar to the billet deformed using route A but, after taking measurements, it was revealed that the height was $9 \mathrm{~mm}$, comparing to the initial $10 \mathrm{~mm}$. Therefore, the lower surface of the billet shown in Figure 7(c) was not in contact with the die during processing. Similarly to billet $\mathrm{B}_{\mathrm{C}}$, the exit channel was not filled completely by the material.

After processing the coarse-grained billets at $523 \mathrm{~K}$ $\left(250{ }^{\circ} \mathrm{C}\right)$ by four passes, two additional passes at $473 \mathrm{~K}$
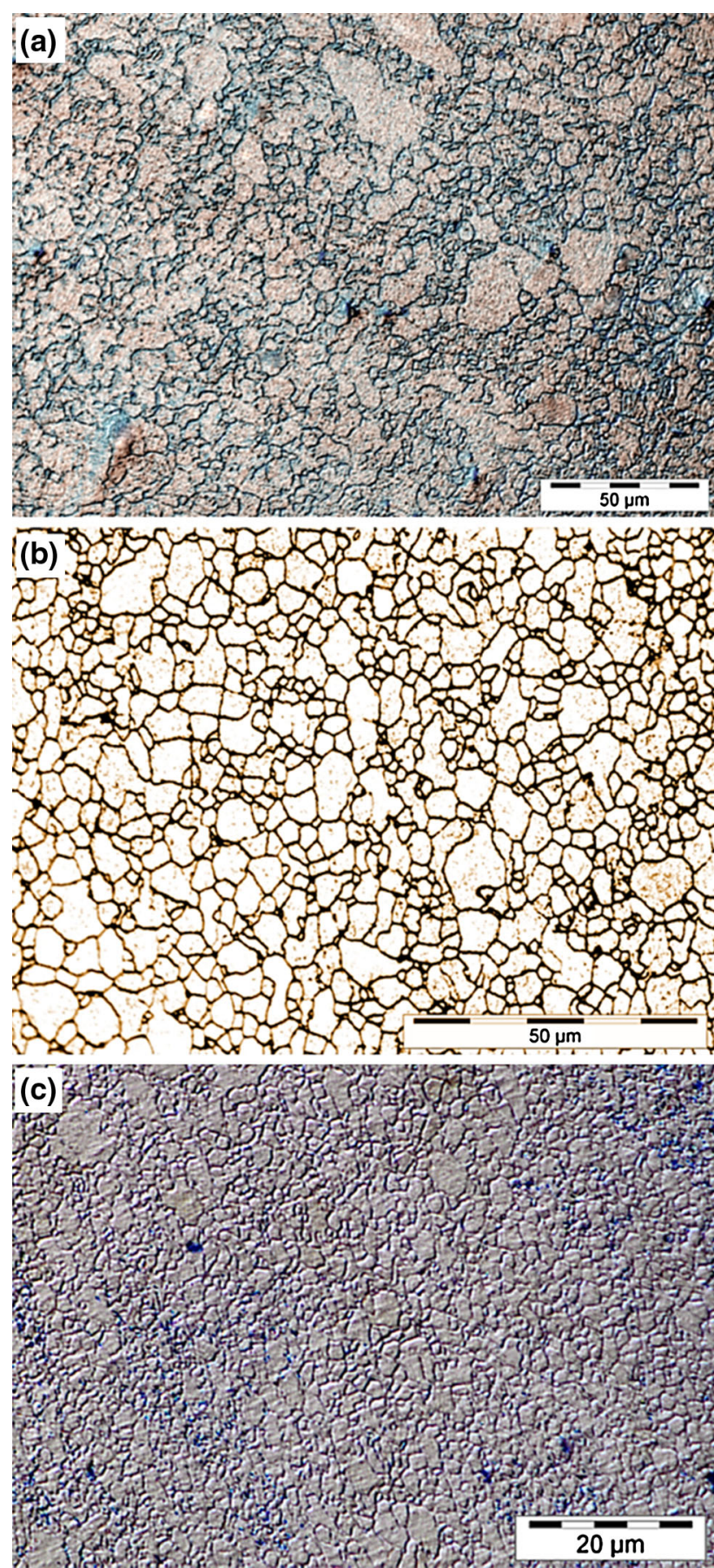

Fig. 5-Optical microscope images of the I-ECAPed samples after (a) two passes at $523 \mathrm{~K}\left(250{ }^{\circ} \mathrm{C}\right)$ (from the rod); (b) four passes at $523 \mathrm{~K}\left(250{ }^{\circ} \mathrm{C}\right)$ (from the rod); $(c)$ one pass at $473 \mathrm{~K}\left(200^{\circ} \mathrm{C}\right)$ and one pass at $448 \mathrm{~K}\left(175^{\circ} \mathrm{C}\right)$ (from the plate).

$\left(200{ }^{\circ} \mathrm{C}\right)$ were conducted for each route in order to investigate the influence of route selection on the occurrence of fracture. Only the billet processed by route A was not damaged after six passes of I-ECAP. Random cracks were observed on the billets processed by route $\mathrm{B}_{\mathrm{C}}$; some billets were completely damaged (Figure $8(\mathrm{a})$ ), while others exhibited only minor cracking. On the other hand, processing at $473 \mathrm{~K}\left(200^{\circ} \mathrm{C}\right)$ always led to the occurrence of large cracks on the billet subjected to route $\mathrm{C}$ 
(a)

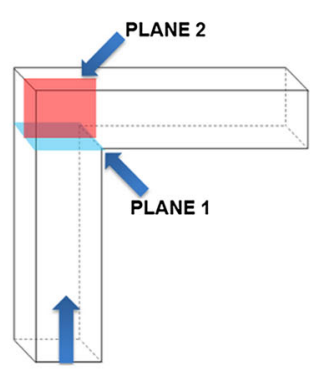

Billet feeding direction
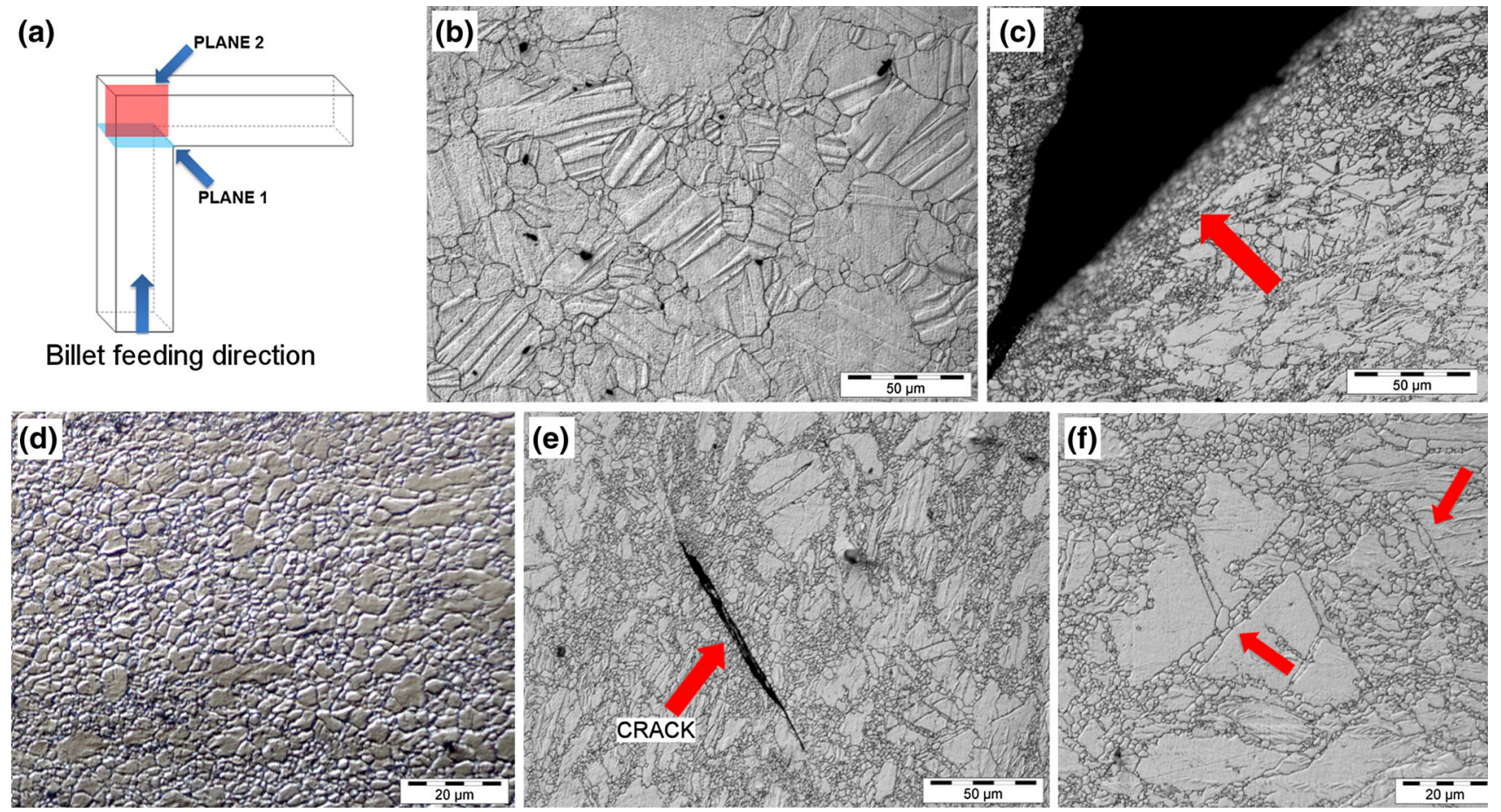

Fig. 6- (a) Planes of the microstructural characterization results shown in images ( $b$ through $f$ ). Optical images of the rod billet (coarse-grained) subjected to interrupted I-ECAP at $473 \mathrm{~K}\left(200^{\circ} \mathrm{C}\right)$ : (b) twins on plane 1 and (c) fine grains in the vicinity of a large crack on plane 2 . Optical images of the plate billet (fine grained) subjected to interrupted I-ECAP at $473 \mathrm{~K}\left(200{ }^{\circ} \mathrm{C}\right)$ : (d) non-twinned structure on plane 1 ; and after I-ECAP at $448 \mathrm{~K}\left(175^{\circ} \mathrm{C}\right)$ : (e) fine grains surrounding microcrack in the shear zone on plane 2 and (f) newly formed grains within twins on the same plane.



(a)

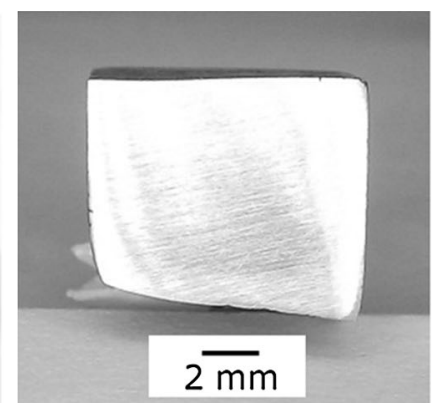

(b)



(c)

Fig. 7-Cross sections of billets processed by four passes of I-ECAP at $523 \mathrm{~K}\left(250{ }^{\circ} \mathrm{C}\right)$ using routes $\mathrm{A}(a), \mathrm{B}_{\mathrm{C}}(b)$, and $\mathrm{C}(c)$. Scale bar in $(\mathrm{b})$ applies to (a) and (c) as well.

(Figure 8(b)). It is worth noting that the fracture initiation points for routes $\mathrm{B}_{\mathrm{C}}$ and $\mathrm{C}$ were located in different zones. For route $\mathrm{B}_{\mathrm{C}}$, fracture started on the billet edge, which did not fill the exit channel (Figure 7(b)) and then propagated to the billet's body along shear planes. For route $\mathrm{C}$, fracture began along the width of the billet's lower surface and further propagation took place along the shear planes.

\section{DISCUSSION}

\section{A. Influence of the Grain Size on Formability During I-ECAP}

The obtained experimental results showed that the initial grain size and microstructure homogeneity of the magnesium alloy had the influence on the minimum allowable temperature of I-ECAP. Temperature of the first successful pass was lower for the fine-grained billets compared to the coarse-grained ones. Moreover, gradual temperature reduction was shown to be successful in lowering temperature for both types of the initial material, which could be attributed to the grain refinement introduced by earlier passes. The role of texture was considered to be not as important as grain size in this study since the $c$-axes of the hexagonal cells in both materials are aligned almost perpendicular to the feeding direction, as it was confirmed by EBSD (Figure 2). Therefore, an emphasis was put on investigating the influence of initial grain size.

Grain refinement to $\sim 6 \mu \mathrm{m}$ through four passes at $523 \mathrm{~K}\left(250{ }^{\circ} \mathrm{C}\right)$ was necessary to successfully lower 

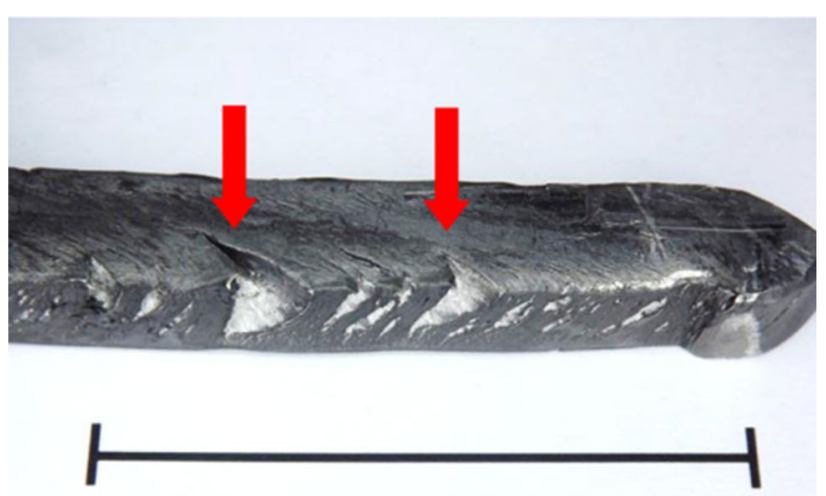

$50 \mathrm{~mm}$

(a)

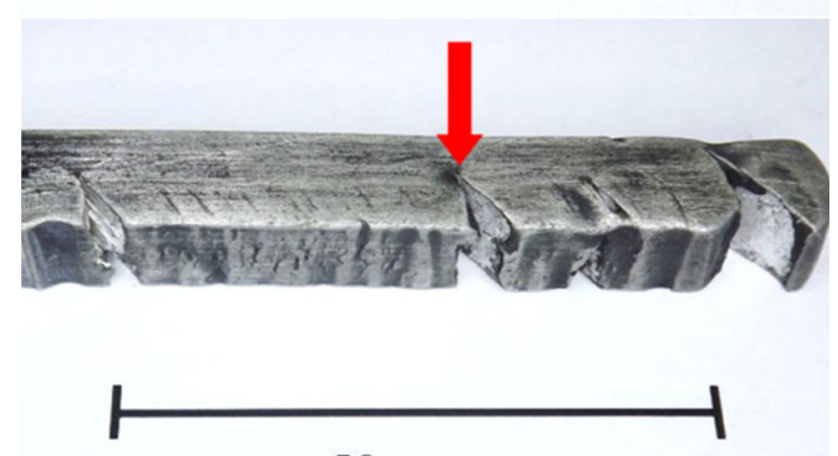

$50 \mathrm{~mm}$

(b)

Fig. 8-Fracture in the coarse-grained billets subjected to four passes at $523 \mathrm{~K}\left(250^{\circ} \mathrm{C}\right)$ and additional two passes at $473 \mathrm{~K}\left(200^{\circ} \mathrm{C}\right)$ by routes $\mathrm{B}_{\mathrm{C}}(a)$ and $\mathrm{C}(b)$.

processing temperature to $473 \mathrm{~K}\left(200^{\circ} \mathrm{C}\right)$ in the case of coarse-grained material. A previous attempt to do this after only two passes resulted in fracture which was attributed to the presence of large grains $(\sim 30 \mu \mathrm{m})$ in the bimodal microstructure. In the case of fine-grained sample, the first attempt at $448 \mathrm{~K}\left(175^{\circ} \mathrm{C}\right)$ was unsuccessful, but when the grain size was reduced by processing at $473 \mathrm{~K}\left(200{ }^{\circ} \mathrm{C}\right)$, subsequent passes were completed at $448 \mathrm{~K}$ and $423 \mathrm{~K}\left(175^{\circ} \mathrm{C}\right.$ and $\left.150^{\circ} \mathrm{C}\right)$. It should be noted that processing at the lower temperature was possible only after grain size refinement to $\sim 1.5 \mu \mathrm{m}$. The question remains how to explain the improved low-temperature formability of the magnesium alloy with grain size reduction?

The optical microscopy images shown in Figure 6 give a partial answer to this question by referring to twins. They show that in fractured samples, twins are formed in the material before it enters the shear zone. Moreover, twins were not observed in the samples which did not fracture. We claim that recrystallization which took place in the twins shown in Figures 6(c) and (e) led to strain localization arising from the stress relaxation in recrystallized zones. The fracture of magnesium alloys due to twinning is widely described in the literature. It was shown by Wonsiewicz and Backofen ${ }^{[27]}$ that basal shear in the twinned volume can lead to strain localization and fracture at room temperature. The similar conclusions were drawn by Barnett ${ }^{[28]}$ and Al-Samman and Gottstein, ${ }^{[29]}$ who reported the occurrence of twins around cracks in AZ31 magnesium alloy and the twinsized voids in fractured samples. Moreover, the platelike voids were observed on the fracture surface of AZ31 subjected to tension, which was attributed to the operation of the twinning-related mechanism of voids formation. ${ }^{[30]}$

Twinning in magnesium alloys is related to grain size and it can be suppressed by refining their structure. This could explain why the gradual reduction of grain size in consecutive passes of I-ECAP helped in lowering temperature. The comprehensive study on the influence of grain size on compression deformation of AZ31 extruded rod was conducted by Barnett et al. ${ }^{[31]}$ The authors showed that deformation mechanism can be switched from twinning dominated to dislocation slip by grain size reduction. The distinctive concave shapes of the compressive flow stress curves, typical for twinned structures, were obtained for grain sizes of 8 to $16 \mu \mathrm{m}$ at $423 \mathrm{~K}\left(150^{\circ} \mathrm{C}\right)$. However, it has changed to convex one (slip dominated) when the grain size was reduced to 3-4 $\mu \mathrm{m}$ (Figure 9(a)). Those literature data give a reasonable explanation of the experimental results obtained in this work. Twinning in the extruded rod, subjected to I-ECAP at $473 \mathrm{~K}\left(200{ }^{\circ} \mathrm{C}\right)$, can be attributed to the large grain size, while suppression of twinning in the plate processed at $473 \mathrm{~K}$ and $448 \mathrm{~K}$ (200 ${ }^{\circ} \mathrm{C}$ and $175^{\circ} \mathrm{C}$ ) can be related to the initially fine-grained structure. Room-temperature uniaxial compression tests were performed for both materials in the as-supplied state. They showed the concave shape of both flow stress curves, which indicates the occurrence of twins (Figure 9(b)). Microstructural characterization after the interrupted I-ECAP showed that temperature increase helped in suppressing twinning observed during roomtemperature compression, but the larger the initial grain size, the higher the temperature was required.

Microstructure homogeneity has also played an important role in suppressing fracture during I-ECAP. It was reported in the past that the presence of heterogeneous, necklace-like structure can result in localization of strain along colonies of recrystallized fine grains in magnesium. ${ }^{[32]}$ It is supported in this work by the occurrence of fine grains around cracks, shown in Figures 6(c) and (e). For example, the fracture of the billet with bimodal microstructure (Figure 5(a)) during I-ECAP at $473 \mathrm{~K}\left(200{ }^{\circ} \mathrm{C}\right)$ can be explained by strain localization in the colonies of fine grains, which were formed along boundaries of coarse grains. Moreover, the as-received rolled plate was successfully subjected to I-ECAP at $473 \mathrm{~K}\left(200^{\circ} \mathrm{C}\right)$ despite the average grain size being almost the same as in the extruded rod after two I-ECAP passes at $523 \mathrm{~K}\left(250{ }^{\circ} \mathrm{C}\right)$, the only difference was distribution of grain size which was more heterogeneous in the latter case.

The non-uniform distribution of grain size leading to strain localization in fine-grained regions can give 


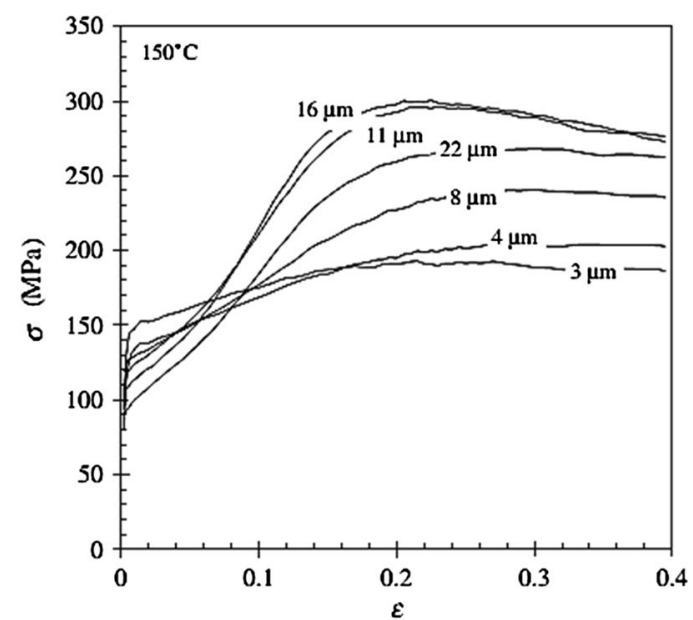

(a)

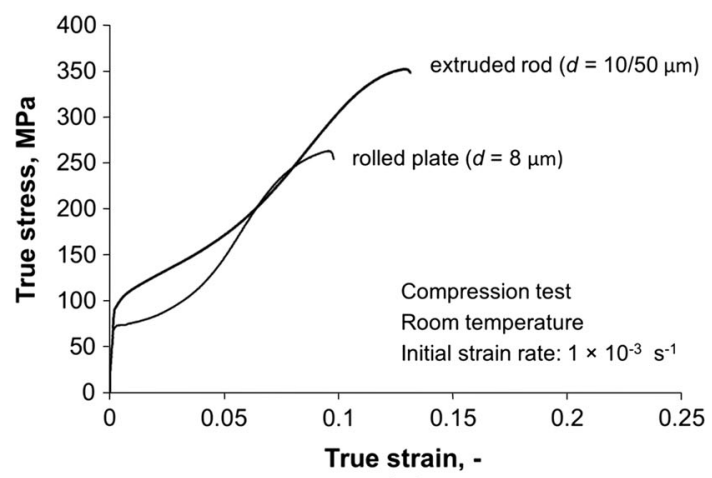

(b)

Fig. 9-Compressive flow stress curves for the AZ31 extruded rod with various grain sizes tested at $423 \mathrm{~K}\left(150{ }^{\circ} \mathrm{C}\right)$ by Barnett et al.$^{[31]}$ (a) and the materials used in this study tested at room temperature $(b)$.

explanation to fracture occurrence when bimodal microstructure is observed. However, literature results show that it is not possible to conduct ECAP even when the structure is homogeneous but grain size is too large. ${ }^{[12,33]}$ It indicates that additional mode of fracture must be activated, and the results obtained in this work show that strain localization in the twinned and subsequently recrystallized volumes can lead to damage of the processed billet. Therefore, we concluded that a finegrained and homogenous microstructure is required to avoid fracture. The small grain size is required to suppress twinning and subsequent strain localization within them, and the homogeneity of structure is needed to avoid strain localization along colonies of fine grains, formed along the boundaries of coarse grains.

\section{B. Influence of Different Routes of I-ECAP on Material Flow and Damage}

The effect of processing route on the material flow and damage was investigated in this work as the existing literature provided only limited information on this topic. The asymmetrical shape of the billets processed by routes $\mathrm{B}_{\mathrm{C}}$ and $\mathrm{C}$ can be explained by a rotation applied to the billet between consecutive passes of I-ECAP as

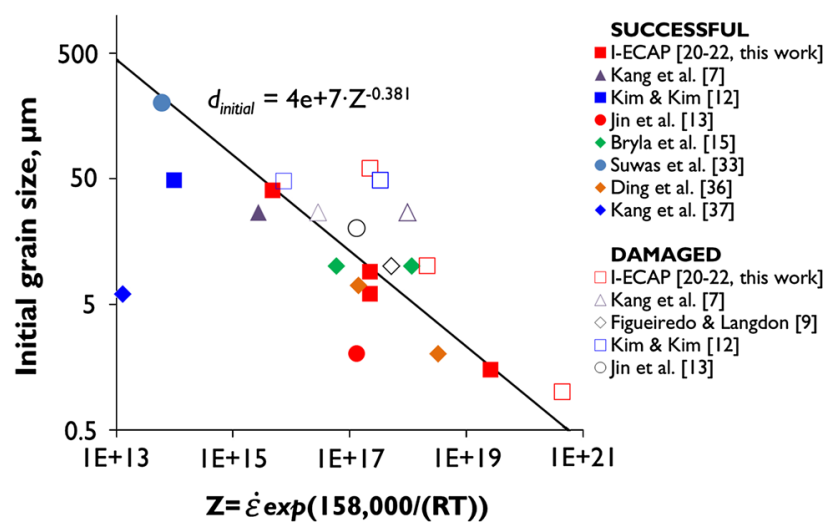

Fig. 10 - Relation between Zener-Hollomon parameter, $Z$, and initial grain size, $d_{\text {initial }}$, in the I-ECAP experiments conducted in this study and supplemented by the literature data for ECAP and IECAP. Filled marks indicate processing without fracture, while hollow marks show when a billet was damaged.

this effect was not observed only after route A (without any rotation). The results of FE simulation confirming that the distortion of the billet displayed in Figure 7(b) can result from a non-uniform distribution of strain rate sensitivity in the billet's cross section were published elsewhere. ${ }^{[20]}$ The experimental results obtained in the current work clearly showed that billets processed via route $\mathrm{A}$ were less prone to fracture than those processed using routes $B_{C}$ and $C$. The different locations of fracture initiation points for routes $\mathrm{B}_{\mathrm{C}}$ and $\mathrm{C}$ suggested that the incomplete filling of the die exit channel can be the cause of material damage, probably due to a reduced mean stress (larger tensile stresses). This conclusion follows an earlier publication, ${ }^{[1]}$ which showed that fracture during ECAP of magnesium alloys is more likely to occur on the billet's surface which loses contact with a die. The authors of ${ }^{[11]}$ also used FE analysis to link the incomplete filling of exit channel with higher damage accumulation (they used a Cockcroft-Latham criterion).

\section{Processing Window}

The results obtained in this work and in our previous study ${ }^{[22]}$ showed that the initial grain size has a strong influence on the minimum temperature of I-ECAP. However, the effect of strain rate cannot be ignored as well; therefore, it is proposed to use a Zener-Hollomon parameter ${ }^{[34]}$ to define the processing window:

$$
Z=\dot{\varepsilon} \exp \left(\frac{Q}{R T}\right)
$$

where $\dot{\varepsilon}$ is the strain rate $\left(\mathrm{s}^{-1}\right), T$ is the temperature $(\mathrm{K})$, $Q$ is the activation energy, $158 \mathrm{~kJ} / \mathrm{mol},{ }^{[35]}$ and $R$ is the gas constant, $8.314 \mathrm{~J} / \mathrm{mol} \mathrm{K}$.

Since I-ECAP experiments were run with the same strain rate $\left(\sim 0.8 \mathrm{~s}^{-1}\right)$, the results of conventional ECAP were derived from the literature to obtain a wide range of temperatures and strain rates. The temperature range 
covered in Figure 10 is $398 \mathrm{~K}$ to $673 \mathrm{~K}\left(125^{\circ} \mathrm{C}\right.$ to $400{ }^{\circ} \mathrm{C}$ ), while the strain rate changes between 0.01 and $1.8 \mathrm{~s}^{-1}$. It is apparent that for greater $Z$ parameter (higher strain rate and/or low temperature) the initial grain size should be relatively fine to enable processing. In the work by $\mathrm{Kim}$ and $\mathrm{Kim},{ }^{[12]}$ coarse-grained AZ31 $(d=48 \mu \mathrm{m})$ was successfully ECAPed at $593 \mathrm{~K}$ $\left(320{ }^{\circ} \mathrm{C}\right)$, while processing at $523 \mathrm{~K}$ and $473 \mathrm{~K}\left(250{ }^{\circ} \mathrm{C}\right.$ and $200{ }^{\circ} \mathrm{C}$ ) resulted in fracture. Suwas et al. ${ }^{[33]}$ were able to decrease temperature to $523 \mathrm{~K}\left(250{ }^{\circ} \mathrm{C}\right)$ even for the very coarse-grained sample $(d=200 \mu \mathrm{m})$ by reducing pressing speed (strain rate $\sim 0.01 \mathrm{~s}^{-1}$ ). In other study, ${ }^{[7]}$ temperature of ECAP was lowered to $473 \mathrm{~K}$ $\left(200{ }^{\circ} \mathrm{C}\right)$ by decreasing strain rate to $0.02 \mathrm{~s}^{-1}$ for the alloy with an initial grain size of $27 \mu \mathrm{m}$. Nevertheless, fine structure with the average grain size of $\sim 10 \mu \mathrm{m}$ is usually required to ECAP magnesium alloys at this temperature with higher speed. Figueiredo and Langdon $^{[9]}$ reported fracture when AZ31 $(d=9.4 \mu \mathrm{m})$ was pressed with strain rate $1.8 \mathrm{~s}^{-1}$, while Ding et al. ${ }^{[36]}$ successfully pressed the same alloy $(d=7 \mu \mathrm{m})$ with strain rate $0.5 \mathrm{~s}^{-1}$. In order to reduce temperature below $473 \mathrm{~K}\left(200^{\circ} \mathrm{C}\right)$, the grain structure of $\sim 2 \mu \mathrm{m}$ or smaller is required. ${ }^{[13,22,36]}$ It was found here that the relation between Zener-Hollomon parameter, $Z$, and the initial grain size of AZ31 required to avoid fracture, $d_{\text {initial }}$, follows the power law:

$$
d_{\text {initial }}=A Z^{-n}
$$

where $A=4 \mathrm{e}+7$ and $n=0.381$.

\section{CONCLUSIONS}

The I-ECAP experiments were conducted in this work at temperatures ranging from $398 \mathrm{~K}$ to $523 \mathrm{~K}\left(125^{\circ} \mathrm{C}\right.$ to $250^{\circ} \mathrm{C}$ ) using various processing routes, namely $\mathrm{A}$, $\mathrm{B}_{\mathrm{C}}$, and $\mathrm{C}$. The main conclusions drawn from this work are as follows:

1. Initial grain size of AZ31B magnesium alloy has strong effect on the minimum temperature of I-ECAP; a fine-grained and homogenous microstructure is required to avoid fracture at low temperatures.

2. Strain localization arising from the stress relaxation within recrystallized regions, namely twins and fine-grained zones, was shown to be responsible for the generation of microcracks.

3. The proposed relation between initial grain size and processing conditions, described by the ZenerHollomon parameter, follows the power law for I-ECAP and ECAP experiments; it shows that the results obtained from both processes are comparable.

4. Processing route has the influence on the material flow and fracture behavior during I-ECAP, and route $\mathrm{A}$ was shown to be less prone to fracture than $\mathrm{B}_{\mathrm{C}}$ and $\mathrm{C}$. This observation can be applied to conventional ECAP as well.

\section{ACKNOWLEDGMENTS}

Financial support from Carpenter Technology Corporation is kindly acknowledged. Part of this research was supported by the Engineering and Physical Sciences Research Council [Grant Number EP/G0347 $7 \mathrm{X} / 1]$.

\section{REFERENCES}

1. V.M. Segal, V.I. Reznikov, A.E. Drobyshevskiy, and V.I. Kopylov: Russ. Metall. (Metally), 1981, vol. 1, pp. 99-105.

2. V.M. Segal: Mater. Sci. Eng., A, 1995, vol. 197, pp. 157-64.

3. T.G. Langdon: Mater. Sci. Eng., A, 2007, vol. 462, pp. 3-11.

4. T. Mukai, M. Yamanoi, H. Watanabe, and K. Higashi: Scripta Mater., 2001, vol. 45, pp. 89-94.

5. S.X. Ding, W.T. Lee, C.P. Chang, L.W. Chang, and P.W. Kao: Scripta Mater., 2008, vol. 59, pp. 1006-09.

6. D. Orlov, K.D. Ralston, N. Birbilis, and Y. Estrin: Acta Mater., 2011, vol. 59, pp. 6176-86.

7. F. Kang, J.T. Wang, and Y. Peng: Mater. Sci. Eng., A, 2008, vol. 487 , pp. $68-73$.

8. R. Lapovok, Y. Estrin, M.V. Popov, and T.G. Langdon: $A d v$. Eng. Mater., 2008, vol. 10, pp. 429-33.

9. R.B. Figueiredo and T.G. Langdon: Mater. Sci. Eng., A, 2009, vol. 501, pp. 105-14.

10. R. Lapovok: J. Mater. Sci., 2005, vol. 40, pp. 341-46.

11. R.B. Figueiredo, P.R. Cetlin, and T.G. Langdon: Acta Mater., 2007, vol. 55 , pp. $4769-79$.

12. H.K. Kim and W.J. Kim: Mater. Sci. Eng., A, 2004, vol. 385, pp. $300-08$.

13. L. Jin, D. Lin, D. Mao, X. Zeng, B. Chen, and W. Ding: Mater. Sci. Eng., A, 2006, vol. 423, pp. 247-52.

14. S. Biswas, S.S. Dhinwal, and S. Suwas: Acta Mater., 2010, vol. 58, pp. 3247-61.

15. K. Bryla, J. Dutkiewicz, and P. Malczewski: Arch. Mater. Sci. Eng., 2009, vol. 40, pp. 17-22.

16. A. Rosochowski and L. Olejnik: in Proceedings of the 10th International Conference on Material Forming, Esaform 2007, E. Cueto, and F. Chinesta, eds., American Institute of Physics, Zaragoza, Spain, 18-20 April, 2007, vol. 907, pp. 653-58.

17. A. Rosochowski and L. Olejnik: Mater. Sci. Forum, 2011, vol. 674, pp. 19-28.

18. A. Rosochowski, L. Olejnik, and M. Richert: Mater. Sci. Forum, 2008, vols. 584-586, pp. 108-13.

19. A. Rosochowski, M. Rosochowska, L. Olejnik, and B. Verlinden: Steel Res. Int., 2010, vol. 81, pp. 470-73.

20. M. Gzyl, A. Rosochowski, E. Yakushina, P. Wood, and L. Olejnik: Key Eng. Mater., 2013, vols. 554-557, pp. 876-84.

21. M. Gzyl, A. Rosochowski, R. Pesci, L. Olejnik, E. Yakushina, and P. Wood: Metall. Mater. Trans. A, 2014, vol. 45A, pp. 1609-20.

22. M. Gzyl, A. Rosochowski, L. Olejnik, and A. Reshetov: Key Eng. Mater., 2014, vols. 611-612, pp. 573-80.

23. M. Gzyl, A. Rosochowski, S. Boczkal, and L. Olejnik: Mater. Sci. Eng., A, 2015, vol. 638, pp. 20-29.

24. A. Rosochowski, L. Olejnik, and M. Richert: Mater. Sci. Forum, 2008, vols. 584-586, pp. 139-44

25. M. Janecek, M. Popov, M.G. Krieger, R.J. Hellmig, and Y. Estrin: Mater. Sci. Eng., A, 2007, vol. 462, pp. 116-20.

26. M. Gzyl, A. Rosochowski, A. Milenin, and L. Olejnik: Comput. Methods Mater. Sci., 2013, vol. 13, pp. 357-63.

27. B.C. Wonsiewicz and W.A. Backofen: Trans. TMS-AIME, 1967, vol. 239, pp. 1422-31

28. M.R. Barnett: Mater. Sci. Eng., A, 2007, vol. 464, pp. 8-16.

29. T. Al-Samman and G. Gottstein: Mater. Sci. Eng., A, 2008, vol. 488, pp. 406-14.

30. M. Marya, L.G. Hector, R. Verma, and W. Tong: Mater. Sci. Eng., A, 2006, vol. 418, pp. 341-56.

31. M.R. Barnett, Z. Keshavarz, A.G. Beer, and D. Atwell: Acta Mater., 2004, vol. 52, pp. 5093-5103. 
32. S.E. Ion, F.J. Humphreys, and S.H. White: Acta Metall., 1982, vol. 30, pp. 1909-19.

33. S. Suwas, G. Gottstein, and R. Kumar: Mater. Sci. Eng., A, 2007, vol. 471 , pp. 1-14.

34. C. Zener and J.H. Hollomon: J. Appl. Phys., 1944, vol. 15, pp. $22-32$
35. I. Schindler, P. Kawulok, E. Hadasik, and D. Kuc: J. Mater. Eng. Perform., 2013, vol. 22, pp. 890-97.

36. S.X. Ding, C.P. Chang, and P.W. Kao: Metall. Mater. Trans. A, 2009, vol. 40A, pp. 415-25

37. S.H. Kang, Y.S. Lee, and J.H. Lee: J. Mater. Process. Technol., 2008, vol. 201, pp. 436-40. 